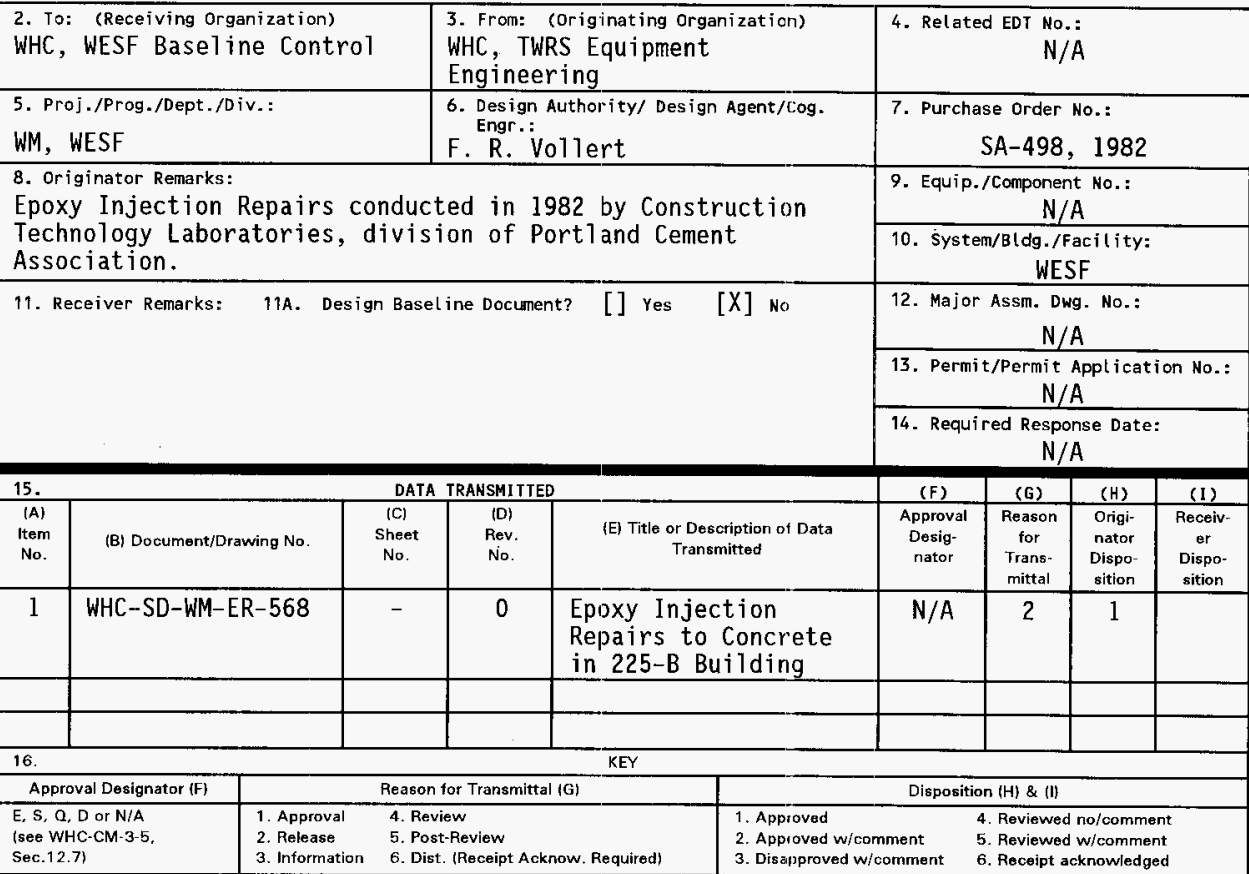

\begin{tabular}{|c|c|c|c|c|c|c|c|c|}
\hline \multicolumn{9}{|c|}{$\begin{array}{l}\text { 17. SIGNATUFE/DISTRIBUTION } \\
\text { ISee Approval Designator for required signaturest }\end{array}$} \\
\hline \multirow[t]{3}{*}{$\begin{array}{l}\text { (G) } \\
\text { Rea- } \\
\text { son }\end{array}$} & $\begin{array}{l}\text { (H) } \\
\text { Dis } \\
\text { p. }\end{array}$ & (J) Name & (K) Signature & (M) MSIN & $\begin{array}{c}\text { (G) } \\
\text { Rea- } \\
\text { son }\end{array}$ & $\begin{array}{l}\text { (H) } \\
\text { Dis } \\
\text { p. }\end{array}$ & \multicolumn{2}{|r|}{ (K) Signature } \\
\hline & & \multicolumn{3}{|c|}{ Design Authority N/A } & 1,2 & 1 & \multicolumn{2}{|c|}{ k. v. scott 7 (vileg) $9-16-9 a^{\mathrm{H5}-52}$} \\
\hline & & \multicolumn{3}{|c|}{ Design Agent N/A } & & & \multicolumn{2}{|c|}{ 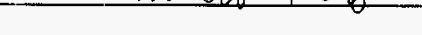 } \\
\hline 1,2 & 1 & \multicolumn{7}{|c|}{ Cog.Eng. F. R. voltert 7. } \\
\hline 1,2 & 1 & \multicolumn{7}{|c|}{ Cog. Mgr. W. W. Jenkins $(1)$ ( $<9|6| \%$ \$2-27 } \\
\hline & & \multicolumn{7}{|c|}{ QA N/A } \\
\hline & & \multicolumn{7}{|l|}{ Safety N/A } \\
\hline & & \multicolumn{7}{|l|}{ Env. $N / A$} \\
\hline \multicolumn{3}{|c|}{$\begin{array}{l}18 . \\
\text { F. B Volleyt } \\
\text { Signature of EDT } \\
\text { Originator }\end{array}$} & \multicolumn{2}{|c|}{$\begin{array}{l}\text { Authorized Representative Date } \\
\text { for Receiving Organization }\end{array}$} & \multicolumn{3}{|c|}{$\begin{array}{l}20 . \\
\text { Desiqu Authorityf } \\
\text { Cognizat Manager }\end{array}$} & $\begin{array}{l}\text { 21. DOE APPROVAL (if required) } \\
\text { Ctrl. No. } \\
\text { [] Approved } \\
\text { [] Approved w/comments } \\
\text { [] Disapproved w/comments }\end{array}$ \\
\hline
\end{tabular}

BD-7400-172-2(05/96) GEF097 


\title{
Epoxy Injection Repairs to Concrete in 225-B Building
}

\author{
F. R. Vollert \\ Westinghouse Hanford Company, Richland, WA 99352 \\ U.S. Department of Energy Contract DE-AC06-87RL10930
EDT/ECN: 618831
Org Code: $74 \mathrm{~F} 10$
UC: 2000
B\&R Code: EW3135090
Charge Code: E51162 or KW4CS
Total Pages: 19

Key Words: Reinforced Concrete, Epoxy Injection Repairs,

Abstract: In 1982, the damaged anchor areas (67 tota1) in the Operating Gallery and cold manipulator shop ceiling reinforced concrete slabs were epoxy injection repaired by Construction Technology Laboratories (CTL), Portland Cement Association. The through depth vertical cracks (10 total) in the ceiling slabs in the galleries and manipulator shops were sealed and structurally repaired using epoxy injection procedures. The details of the epoxy repair are reported. Sonic nondestructive (NDT) testing before and after the epoxy injection repairs were made by CTL to confirm that the repairs are structurally effective. CTL recommended to expedite the installation of lateral bracing for the manipulator monorail in order to avoid re-damage to the repaired anchor areas.

IRADEMARK DISCLAIMER. Reference herein to any specific commercial product, process, or service by trade name, trademark, manufacturer, or otherwise, does not necessarily constitute or imply its endorsement, recommendation, or favoring by the United States Government or any agency thereof or its contractors or subcontractors.

Printed in the United States of America. To obtain copies of this document, contact: WHC/BCS Document Control Services, P.O. Box 1970, Mailstop H6-08, RichLand WA 99352, Phone (509) 372-2420; Fax (509) 376-4989.
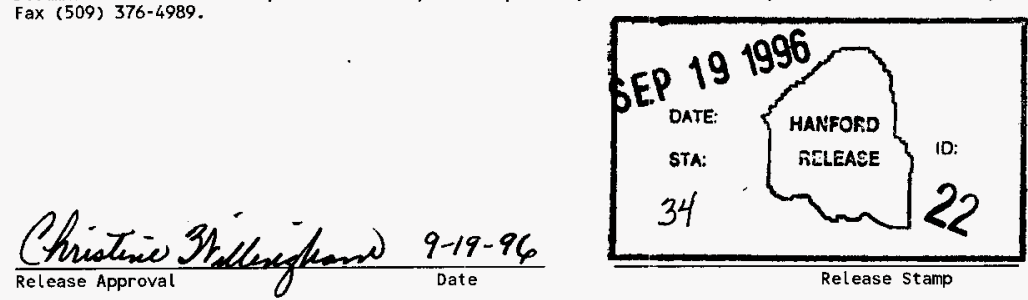

Approved for Public Release 
WHC-SD-WM-E:R-568 Rev. 0

EPOXY INJECTION REPAIRS TO

CONCRETE IN 225-B BUILDING

WESTINGHOUSE HANFORD COMPANY

September 1996

For the U.S. Department of Energy Contract DE-AC06-87RL10930 
WHC-SD-WM-IR-568 Rev. 0

This page intentionally left blank. 
WHC-SD-WM-ER-568 Rev. 0

COWTENTS

1.0 HIGHLIGHTS . . . . . . . . . . . . . . . . . . . . 1

2.0 DESCRIPTION OF 225-B BUILDING . . . . . . . . . . . . . . 2

3.0 EPOXY REPAIR PROGRAM . . . . . . . . . . . . . . . . 4

4.0 NONDESTRUCTIVE TEST PROGRAM . . . . . . . . . . . . . . . 13

5.0 SUMMary . . . . . . . . . . . . . . . . . . . . . . 16

6.0 REFERENCES . . . . . . . . . . . . . . . . . . . . . 19

7.0 APPENDIX A - EPOXY REPAIR INFORMATION . . . . . . . . . A-i

\section{LIBT OF FIGURES}

1. Cross Section - 225B Building . . . . . . . . . . . . . . 5

2. Condition of Concrete at Anchor Area Location MI-28 Before and After Injection of Epoxy . . . . . . . . . . 14

3. Condition of Concrete at Anchor Area Location $\mathrm{MI}-25$ Before and After Injection of Epoxy . . . . . . . . . . 15

4. Condition of Concrete in Cracked Area in Hot Manipulator shop Ceiling Slab Before and After Injection of Epoxy . . . . . . . . . . . . . . . . 17

\section{LIST OF TABLES}

1. Repairs to operating Gallery Ceiling slab - Building 225-B . . . . . . . . . . . . . . . . . . . . 6

2. Repairs to Cold Manipulator shop Ceiling slab Building 225-B.......... . . . . . . . . . . 11 
WHC-SD-WM-ER-568 Rev. 0

This page intentionally left blank. 


$$
\text { WHC-SD-WM-ER-568 Rev. } 0
$$

\section{FINAL REPORT}

EPOXY INJECTION REPAIRS TO CONCRETE IN 225-B BUILDING

by

Melvin S. Abrams and Richard A. Muenow

\subsection{HIGHLIGHTS}

This report summarizes details of an epoxy injection repair program and results of a sonic nondestructive (NDT) program conducted in the 225-B Building for Rockwell Hanford Operations (Rockwell), Richland, Washington.

Damage to concrete of the ceiling slab of the operating gallery, the ceiling slab of the service gallery (canyon floor), the ceiling slab of the cold manipulator shop, and the ceiling slab of the hot manipulator shop was repaired by use of epoxy injection technigues. A nondestructive test program was conducted to evaluate the effectiveness of repairs to damaged concrete areas. Repair and test programs were authorized by Rockwell International Corporation's Supplement No. 1 to Service Agreement SA-498, Prime Contract No. DE-AC06-77RL01030 dated September 1, 1982.

Fifty-one anchor areas were repaired in the operating gallery ceiling slab and sixteen anchor areas were repaired in the cold manipulator shop ceiling slab. Four cracks in the operating gallery ceiling slab, four cracks in the cold manipulator shop ceiling slab, one crack in the hot manipulator shop ceiling slab, and one crack in the service gallery ceiling slab (canyon floor), were also repaired. Nondestructive tests 


$$
\text { WHC-SD-WM-ER-568 Rev. } 0
$$

were conducted on all repaired areas after sufficient time elapsed to permit setting and strength gain of the epoxy material.

Repair and test programs were under the supervision of Melvin S. Abrams, Director, Fire Research Department, Construction Technology Laboratories (CTL), a division of the Portland Cement Association and Richard A. Muenow, a Portland Cement Association Associate. Epoxy repair work was performed by Construction Adhesive Bonding Inc., a subcontractor to the Portland Cement Association.

Results of the nondestructive tests indicated that epoxy injection techniques were effective in repairing the damaged concrete at seiected anchor areas in the operating gallery ceiling slab and cold manipulator shop ceiling slab. Test results also indicated that the cracks in the operating gallery ceiling slab, the cold manipulator shop ceiling slab, hot manipulator shop ceiling slab, and service gallery ceiling slab (canyon floor) were effectively sealed with epoxy material.

Test programs were conducted between September 13 and September 28,1982 .

\subsection{DESCRIPTION OF 225-B BUILIING}

The 225-B Building is a two story structure 157-ft long $x$ 97-ft wide $\times$ 40-ft high at the outside dimensions. The building has a combined floor area of approximately 20,000 sq ft. This area includes $14,000 \mathrm{sq}$ ft on the first floor and $6,000 \mathrm{sq} \mathrm{ft}$ on the second floor. The floor plan is partitioned into 
several areas according to functional reguirements. These areas include:
(a) Process hot cell area
(b) Hot cell service areas
(c) Operating areas
(d) Building service areas
(e) Storage pool area

The partition floor plan regulates flow of personnel and material traffic throughout the building and limits access to areas with potential contamination and/or high radiation. These areas are interrelated and must function as an integrated system to assure a safe operating facility.

\section{Process Hot Cell Area}

The chemical processing and encapsulation of the radioactive isotopes ${ }^{90} \mathrm{SR}$ and ${ }^{137} \mathrm{Cs}$ is accomplished in six remote manipulator-operated hot cells. Exterior walls of hot cells are 35-in. thick and are constructed from reinforced high density concrete (235 lb/cu ft) for structural and radiation shielding requirements. All walls of A Cell and G Cell are constructed of 35-in. thick high density concrete for radiation shielding because they are personnel entry hot cells. Walls between cells are 20-in. thick and are constructed from reirforced normal weight structural concrete (150 lb/cu ft) equipped with a special transfer drawer that is accessible from the service gallery.

All cells have a window in the operating gallery wall. A view of the interior surface of the service gallery wall and of 


\section{WHC-SD-WM-ER-568 Rev. 0}

about $2 / 3$ of the floor area is available through these view.ing windows.

A section through the $225-\mathrm{B}$ Building is shown in Fig. J. The cold manipulator shop is located at the east end of the building adjacent to the operating gallery. The hot manipulator shop is adjacent to the south end of the cold manipulator shop.

\subsection{EPOXY INJECTION REPAIR PROGRAM}

A total of 67 anchor areas were repaired. Fifty-one were located in the operating gallery ceiling slab and 16 were located in the cold manjpulator ceiling slab. An anchor area is defined as the area of concrete surrounding threaded anchors installed in the ceiling. These anchors hold monorail hangar rods.

Four cracks in the operating gallery ceiling slab, four cracks in the cold manipulator shop ceiling slab, one crack in the hot manipulator ceiling slab, and one crack in the service gallery ceiling slab (canyon floor) were sealed by the use of epoxy injection procedures. General epoxy repair information is given in Appendix A. Details of the epoxy repair program follow.

\section{Operating Galley Ceiling Repairs}

Fifty-one anchor areas were injected with epoxy in the ceiling slab of the operating gallery. Designation and location of these areas are given in Table 1. Anchor areas of the majn track are designated by $M-$. Anchor areas on track interchanges are designated by MI-. Anchor areas on the west 


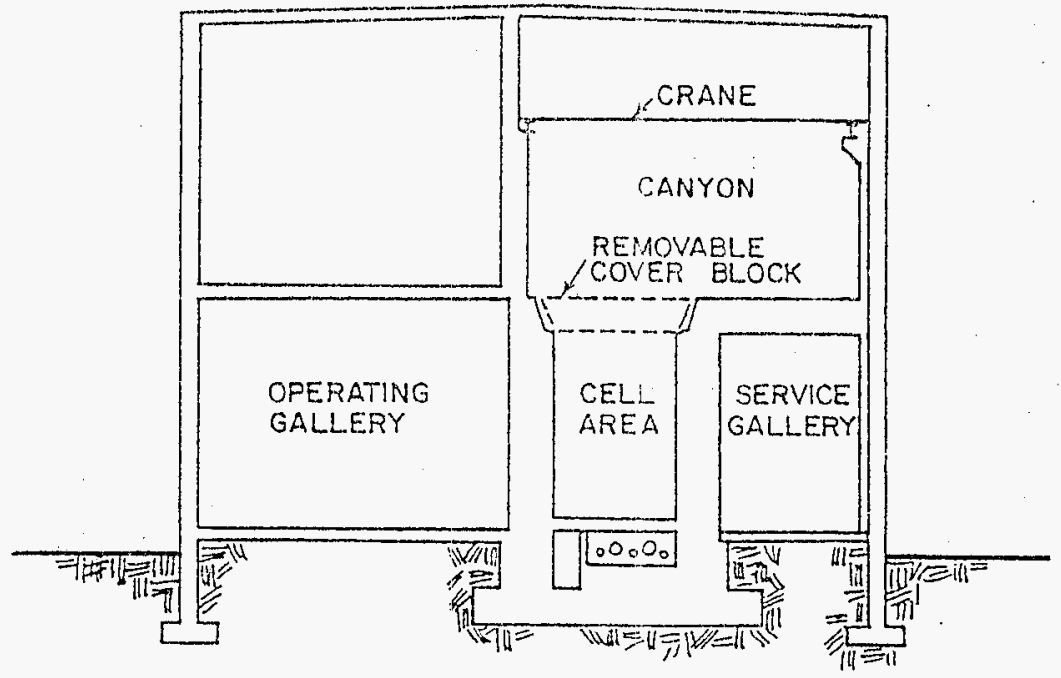

Fig. 1 Cross Section - $225 \mathrm{~B}$ Building 
WHC-SD-WM-ER-568 Rev. 0

'LABLE: 2.

REPAIRS TO ODERATING GALLTRY CEILING SLAB - BUIIDING 225-B

\begin{tabular}{|c|c|c|c|c|c|c|c|}
\hline $\begin{array}{c}\text { Area }(a) \\
\text { Identification }\end{array}$ & $\begin{array}{c}\text { Cel1 }{ }^{(b)} \\
\text { Identification }\end{array}$ & \multicolumn{6}{|c|}{ Remarks } \\
\hline$M I-1$ & $\pi$ & Interchange & .. East & Part & of & Operating & lery \\
\hline$M I-2$ & is & $"$ & $"$ & $"$ & $"$ & $"$ & $"$ \\
\hline $\mathrm{MI}-3$ & $\lambda$ & $"$ & $"$ & $"$ & $"$ & $"$ & $"$ \\
\hline$M I-4$ & $A$ & $" 1$ & $"$ & $"$ & $"$ & $"$ & $"$ \\
\hline$M I-5$ & A. & " & $"$ & $"$ & $"$ & $"$ & $"$ \\
\hline$M I-6$ & A & $"$ & " & $"$ & $"$ & $"$ & $"$ \\
\hline $\mathrm{MI}-7$ & AH & $"$ & $"$ & $"$ & $"$ & $"$ & $"$ \\
\hline$M I-8$ & $\mathrm{AH}$ & $"$ & $"$ & $"$ & $"$ & $"$ & $"$ \\
\hline$M I-9$ & A. $\mathrm{F} t$ & $" 1$ & $"$ & $"$ & $"$ & $"$ & $"$ \\
\hline$M-10$ & - & Main Track & & & & & \\
\hline$M I-13$ & $\underline{3}$ & Interchange & -. East & Part & of & Operating & Iery \\
\hline$M I-14$ & $\mathrm{E3}$ & $"$ & $"$ & 17 & $"$ & $"$ & $"$ \\
\hline$M I-15$ & $\mathrm{~B}$ & $"$ & $"$ & $"$ & " & $"$ & $"$ \\
\hline$M I-16$ & $B$ & $"$ & " & " & * & $"$ & $"$ \\
\hline$M I-17$ & $B$ & $"$ & " & $"$ & $"$ & $"$ & $"$ \\
\hline$M I-18$ & B & $"$ & $"$ & $"$ & $"$ & $"$ & $"$ \\
\hline$M I-20$ & C & Interchange & Gentrai. & 1. Part & of & $=$ Operatin & 1lery \\
\hline$M I-2 I$ & $C$ & $"$ & $"$ & $"$ & $"$ & $"$ & $"$ \\
\hline$M I-22$ & $\mathrm{C}$ & $"$ & $"$ & " & $"$ & $"$ & $"$ \\
\hline$M I-25$ & $c$ & $"$ & " & $"$ & $"$ & " & $"$ \\
\hline$M I-26$ & $\mathrm{D}$ & $"$ & $n$ & $"$ & $"$ & $"$ & $"$ \\
\hline$M I-27$ & D & $"$ & $"$ & $"$ & $"$ & $"$ & $"$ \\
\hline$M I-28$ & $\mathrm{D}$ & " & $"$ & $"$ & $"$ & $"$ & $"$ \\
\hline$M I-29$ & D) & $"$ & $"$ & 1 & $"$ & $"$ & $"$ \\
\hline$M I-30$ & D & $"$ & $"$ & $"$ & $"$ & $"$ & $"$ \\
\hline$M I-31$ & D & $"$ & $"$ & $"$ & $"$ & $"$ & $"$ \\
\hline
\end{tabular}

Note: Repairs at anchor areas of support rods of monorail system

(a) Repair location

(b) Cell serviced by this part of monorail 
WHC-SD-WM-ER-568 Rev. 0

I'able ]. (Continued)

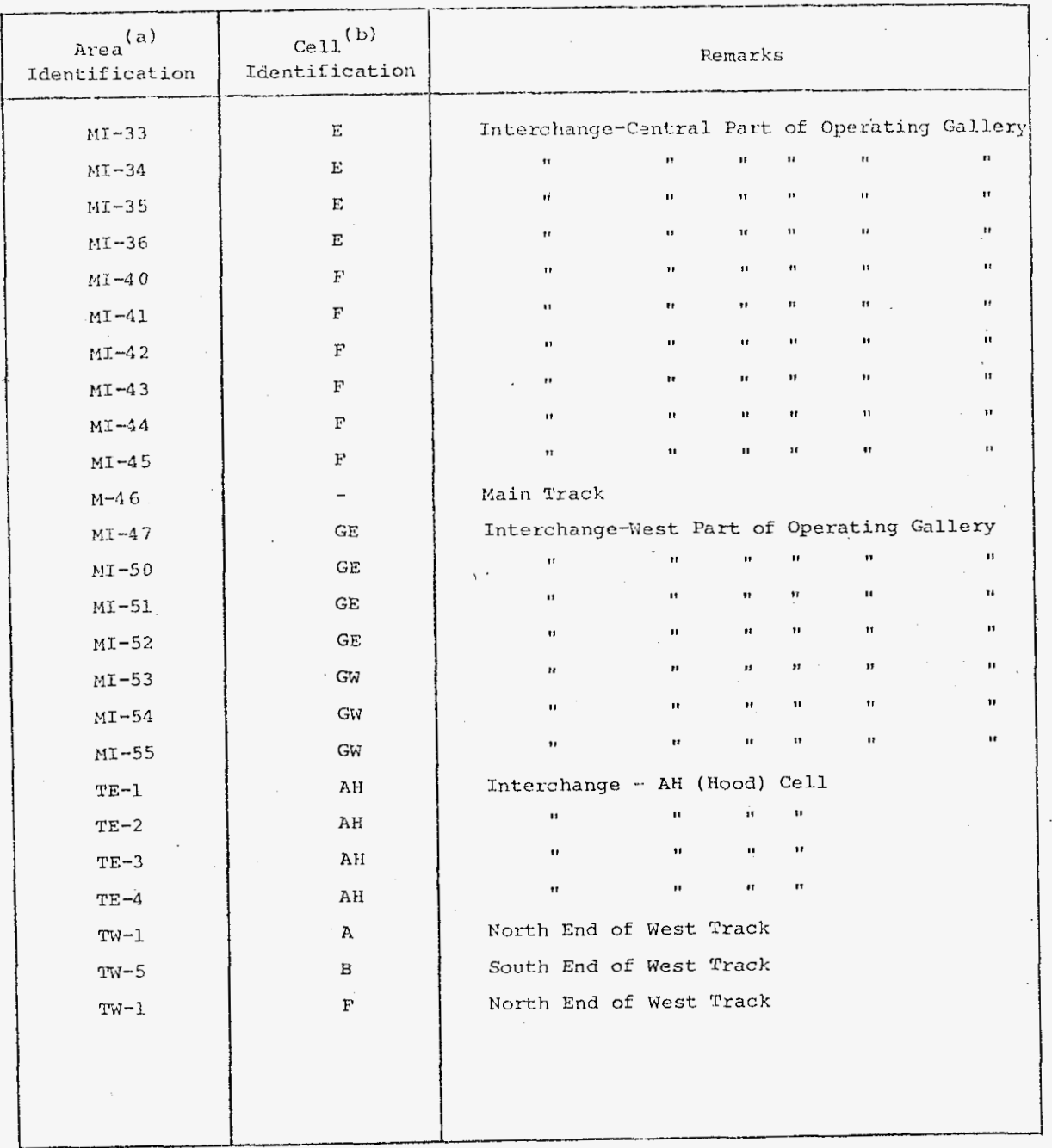


track leading from the majn track to the bell wall are icentified by IW. East track anchor areas are identified by TE. Repairs to the anchor areas were accomplisined in the following manner:

(1) Faint was removed from the bottom of the ceiling siab from a 5-in. diameter circular area centered on the hangar roa.

(2) CONCRESIVE 1438, a two-component epoxy thixotropic surface seal adhesive was applied to the area from which the paint was removed.

(3) A 1./2-in. diameter hole positioned about 2-1/2-in. from the hangar rod was drilled into the ceiling slab at a 45 degree angle. The hole intersected the top of the threaded anchor about $2-1 / 2$ in. from the bottom of the ceiling slab.

(4) Plastic tube injection ports were bonded into drilled holes with the suxface seal adhesive.

(5) The injection nozzle from the pump was attached to the injection port and material pumped into the microcracks and cracks of the concrete in the anchor area until refusal. CONCRESIVE 1077-1, a low viscosity two-component epoxy, specially prepared for a light radiation exposure, was used to repair damaged concrete in the anchor areas.

(6) After repairs were completed, injection ports were removed and repaired areas cleaned. 
WHC-SD-WM-ER-568 Rev. O

No movement of manipulators was allowed in the repaired areas of the monorail system for 24 hours. I.jmited movernent of manipulators was allowed during the 24-hour to 72-hour period after repairs. A period of 72 -hours is required for the ConCRESIVE 1077-l epoxy materjal to gain tull strength.

The foljowjng procedure was used to repair cracks:

(1) Paint was renoved from the botton surface of the ceiling slab for a distance of 1 in. on each side of the crack.

(2) One-half juch diameter holes, I/2-in. deep were drilled into the botton surface of the ceiling silab at the crack location. Holes were spaced on 7 -in. centers,

(3) The crack was sealed with surface seal adhesive CONCRESIVE 1438 on the bottom surface of the ceiling slab.

(4) Injection ports were bonded into the drilled holes with surface seal achesive.

(5) The injection nozzle was attached to injection ports, and CONCRESIVE 1.077-1 epoxy material was pumped into the cracks until refusal.

(6) When the repairs were completed, injection ports were removed and the repaired area cleaned.

Four cracks were repaired in the operating gallery ceiling. Al1. cracks generally ran from north to south. Two cracks were located near D-cell and two cracks were located near Afl (hood) Cell. 
Cold Manipulator Shop Ceiling Repairs

Sixteen anchol areas were injected with epoxy in the ceiling s]ab of the cold manipulator shop. Designation and location of these areas are given in jable 2. Notation in Table 2 is identical to that in Table 1. Additionally, center-track anchor areas in the cold lianipulator shop are identified as CI.

The two cracks mapped during an earlier nondestructive test program $(1) *$, and two cracks not previously detected in the cold manipulator ceiling slab were injected with epoxy. All cracks ran in the east-west direction.

Procedures for repairing anchor areas and cracks in the cold manipulator shop ceiling islab were identical to those described for simjlar repairs in the operating gallery ceiling slab.

Hot Manipulator Shop Ceiling Repairs

No repairs were required to the concrete of the anchor areas of the monorail in the hot manipulator shop. A crack running the full length of the ceiling slab in the east-west direction, not detected during a previous nondestructive test inspection, was repaired. The crack was located about 4-ft south of the north end of the hot manipulator shop. Due to the radiation level in the hot manipulator shop, this crack was cleaned and sealed on the bottom surface of the ceiling slab but repaired from the top surface side on the second floor. Repair procedures are identical to those described for cracks repairs in the operating gallery ceiling slab.

* Numbers in raised parenthesis designate references on Page 19. $-10-$ 
WHC-SD-WM-ER-568 Rev. 0

TABLE 2

REPAIRS TO COLD MANCPULATOR SHOE CEIJING SLAM - BUILDING 225-B

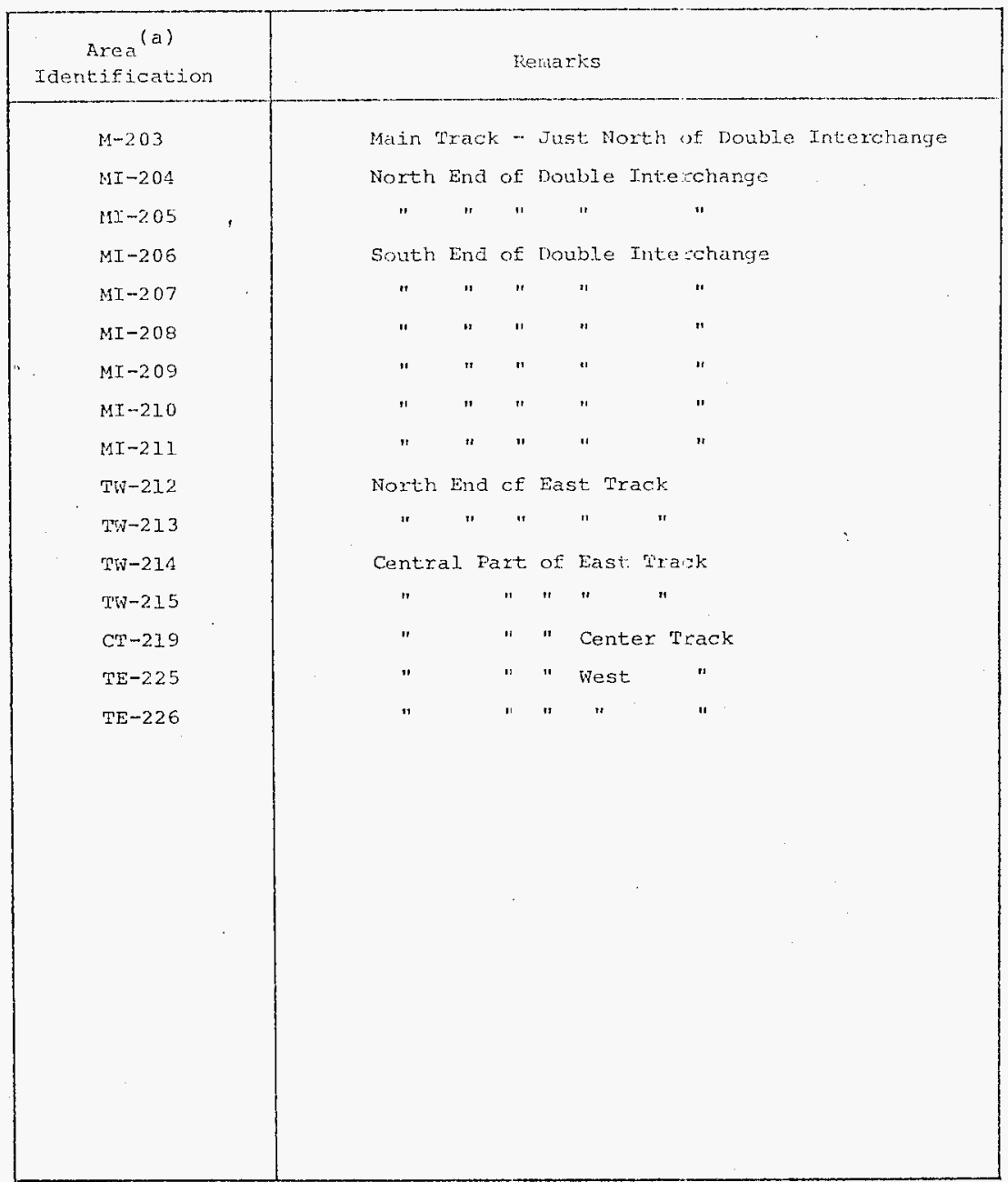

Note: Repairs at anchor areas of support rods of monorail system

(a) Repair Location 
Service Gallery Ceiling (Canyon Floor) Repairs

As proviously reported, a large crack was defected and mapped in the canyon floor slab in the vicinity of D-Cell. The canyon floor slab is 30 -in. thick.

Due to pipes and other obstructions anchored to the cejling of the service gallery, the crack was repaired from the canyon sjde on the second floor. Procedures described for crack repairs in the operating gallery ceiling slab generally were followed with the following exceptions.

(1.) Injection ports vere drilled on l-ft centers.

(2) The crack was injected in two stages: First, epoxy was injected at each injection port location until epoyy material was observed oozing from the crack on the bottom (service gallery) side. After the crack was injected ouring this first stage of the repair procedure, the epoxy material was allowed to set for a short period of time. This setting period sealed the bottom of the crack to prevent any further leakage. The injection procedure was then repeated at all of the injection ports to fill the remainder of: the crack. A large quantity of epoxy material was requirea to seal the crack completely.

Due to the radiation in the canyon area, the injection pump and several other pieces of equipment used in the preparation and crack repair procedures became contaminated and could not be retrieved. 


\section{WHC-SD-WM-ER-568 Rev. 0}

\subsection{NONDESTRUCT IVE T.EST PROGRAI}

To evaluate the extent of penetration and bonding to concrete surfaces of the epoxy material injected into the concrete in the anchor areas and the cracks, nondestructive tests were conducted at all repair Jocations. Fifty-one anchor areas were tested in the operating gallery ceiling siab, and 16 anchor areas in the cold manipulator shop ceiling slab.

All anchor areas, with tre exception of $M-203$ in the cold Inanipulator shop ceiling slab were found to be effectively. sealed with the injected epoxy material. Anchor areas $M-203$ yas subsequently reinjectea.

Figures 2 and 3 show the condition of the concrete before and after epoxy injection at two locations in the operating gallery ceiling slab. At each location, the photograph taken after the epoxy injection shows that the epoxy totally penetrated the microcracks in the areas surrounding the threaded anchor and that the epoxy material bonded to the internal concrete surfaces of the cracks. Discontinlities observed in the photographs taken at each location prior to the injection of the epoxy material are no longer detectable in the photographs taken after the epoxy injection. In the photographs taken after the repairs were made, the concrete at the repaired location appears solia.

To evaluate effectivenes: of the epoxy injection repairs of the cracks in the operating gailery ceiling slab, cold manipulator ceiling slab, hot manipulator shop ceiling slab, and service gallery ceiling slab (canyon floor), nondestructive 


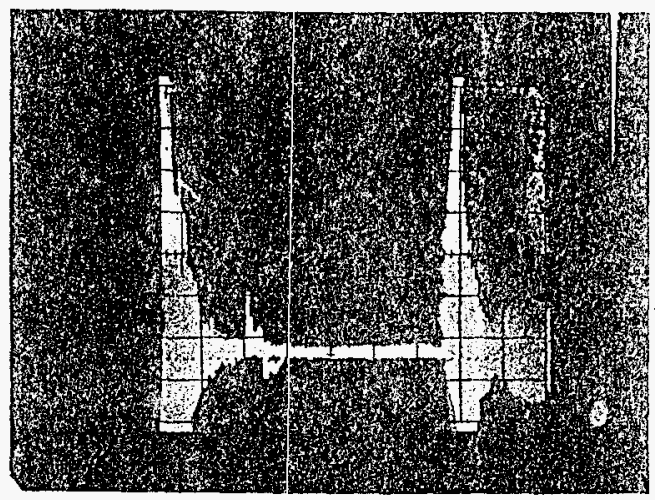

(a) Before Repair - Moderate Mil crocracking From $1 \frac{1}{2}$ to $3 \frac{1}{4}$ in. From Bottom iurface, Crack at I1/ in. From Bottom Surface, Microcracking From $7 \frac{1}{4}$ to $8 \mathrm{in.}$ From Bottom Surface

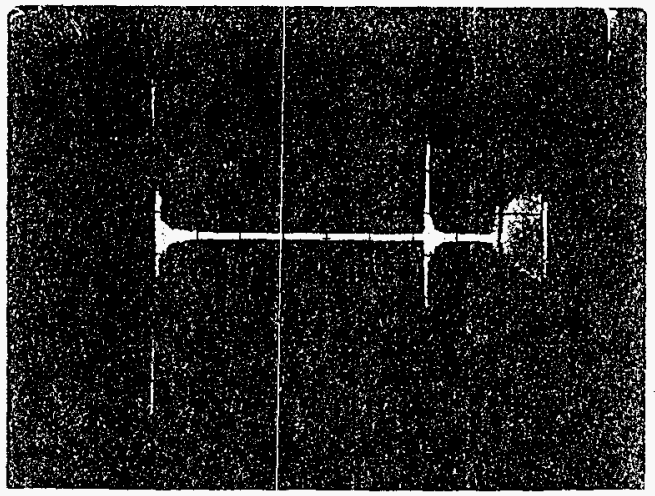

(b) After Repaj.r - Solid Concrete

Fig. 2 Condition of Concrete at Anchor Area Iocation MI-28 Before and After Injection of Epoxy 


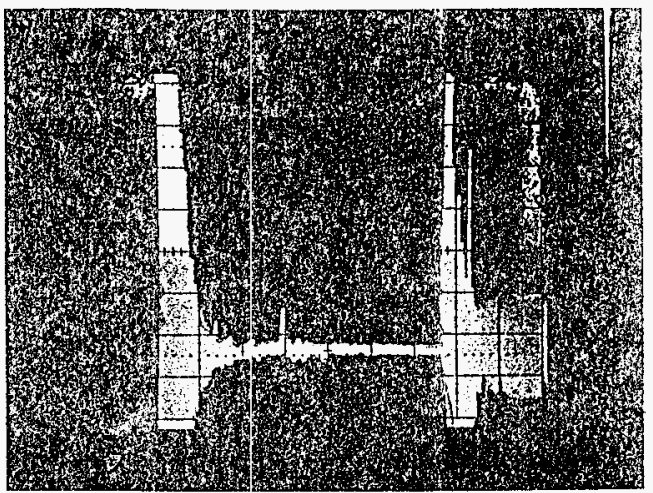

(a) Before Repair - Microcracking From 0 to 1./ in. and From 7th to 8 In. Frm Bottom Surface, Multiple Ljght Cracks at $4-s / 4$ in. From Bottom Surface, crack at $7-3 / 4$ in. From Bottom Surface

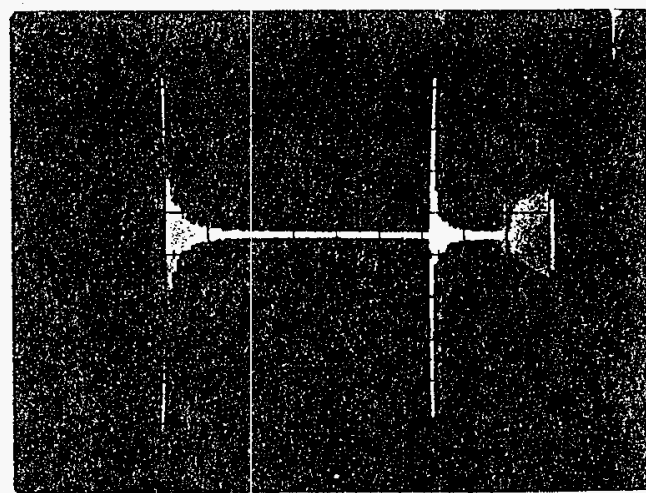

(b) After Repair - Solid concrete

Fig. 3 Condition of Consrete at Anshor Area Location MI-25 Before and After Injertion of Epoxy 
tests were performed on 6 -in. centers or both sides of the repaired cracks for the entire length of the crack. $A 45$ degree angle transhucer was used for this evaluation. Enough tests were made at each location to observe the crack through the entire depth of the slab.

Figure 4 shows a representative photograph of the condition of the crack jn the hot manipulator shop ceiling slab before and after the concrete was injected wjth epoxy. The internal reflector shown in the photograph taken before repairs were made, has been eliminated in the photograph taken after the epoxy was injected. This indicates that the epoxy totally penetrated the crack and bonded to the internal concrete surfiaces of the crack.

Results of the nondestructive evaluation test program indicated that all of the cracks were filled with epoxy material. after repair procedures were completed.

\subsection{SUMMARY}

A total of 67 anchor areas in the perating gallery ceiling slab, and the cold manipulator shop ceiling slab were repaired by the use of an epoxy injecticn technique. Also repaired were four cracks in the operating gallery ceiling slab, four cracks in the cold manipulater shop ceiling slab, one crack in the hot manipulator ceiling slab, and one crack in the service gallery cejling slab (canyor floor). After repairs were completed, a nondestrucive test program was conducted to evaluate the effectiveness of the repai: program. Results of the nondestructive test prog:am indicatod that the injected 
WHC-SD-WM-ER-568 Rev. 0

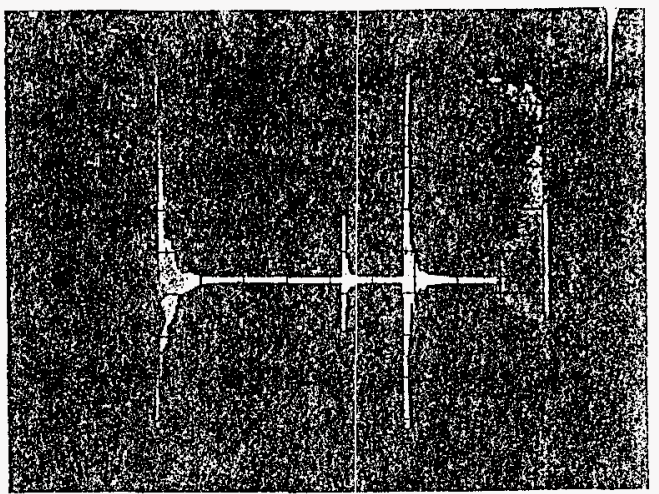

(a) Before Repair - Note Internal Reflector (Crack) in Photograph

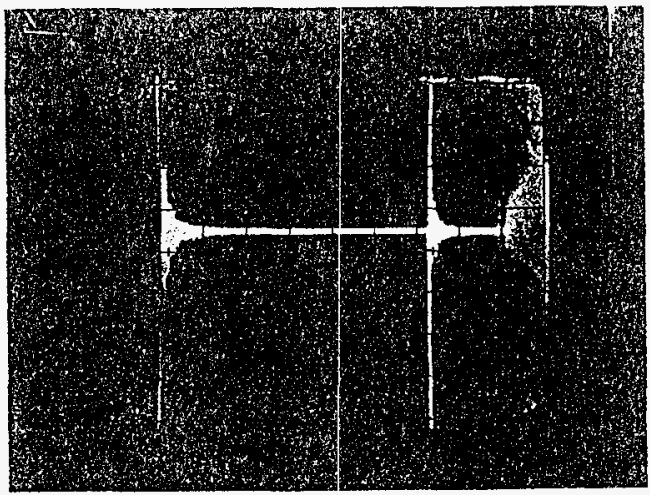

(b) After Repair - Internal Reflector Eliminated Indicating Epoxy Completely Peretrated Crack and Bonded to Internal surfaces

Fig. 4 Condition of concrete in cracked Area in Hot Manipulator shop Ceiling Slab Fefore and After Injection of Epoxy 
WHC-SD-WM-ER-568 Rev. 0

epoxy completely penetrated the cracks in the concrete and bonded to the internal concrete surfaces.

To maintain the integral condition of the concrete that resulted from the epoxy injection repairs, it is recommended that the lateral bracing systen for the monorail be installed as expeditiously as possjble. 
WHC-SD-WM-IR-568 Rev. 0

6.0 REFERENCES

1. Abrans, M. S. and Meunow, R. A., Concrete Nondestructive Iests Conducted in 225-B Building, Construction Technology Laboratories, a Djvision of the portland cement Association, Skokie, IL (September, 1982). 
WHC-SD-WM-ER-568 Rev. O

This page intentionally left blank. 
WHC-SD-WM-ER-568 Rev. 0

AP]PENDIX A

EPOXY REPAIR INFORMA ION

A-i 
WHC-SD-WM-IR-568 Rev. 0

This page intent:onally left blank.

A. $-\mathbf{i}$ 


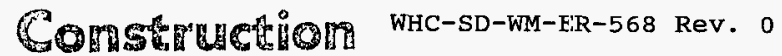

It:e.

TECHNICAL SPECIFICATION RC

FOR

EPOXY INJECTION REPAIR AND NONDESTRUCTIION EVALUATION

OF

MONORAIL SYSTEM BUILOING 2258

HANFORD WORKS

HANFORO WASHINGTON

SPECIFICATION FOR EPOXY INJECTION OF CRACK REPAIR

AND VOLUMEMETRIC REPAIR OF SHATTERED CONCRETE.
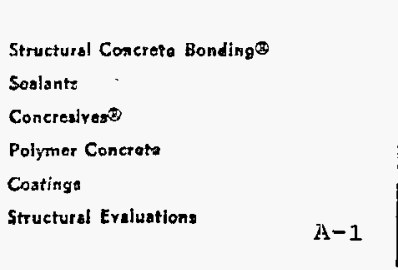
WHC-SD-WM-ER-568 Rev. 0

This page intentionally left blank. 


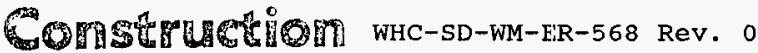

Bonding

inc.

\title{
INFORMATION
}

CONSTRUCTION ADHESIVES BONDING, INC.

CHARLOTTE, NORTH CAROLIMA

EPOXY INJECTION AND NONDESTRUCTIVE EVALUATION

\author{
OF \\ MONORAIL SYSTEM \\ BUILDING $2.25 \mathrm{~B}$ \\ HANFORD WORKS \\ HANFORO, WASHINGTON \\ SEPTEMBER $198 ?$
}

Structural Concroto Bondingt

Soalnnt:

Concresives?

Polymer Concreto

Costings

Telophones:

Structural Evaluation:

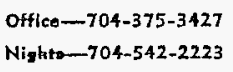


WHC-SD-WM-ER-568 Rev. 0

This page intentionally left blank. 


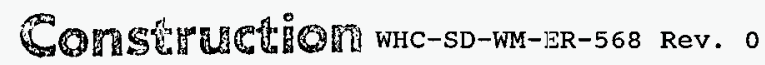
40

onding

face.

\section{JNDEXX}

1. ' Company History

2. Partial Iist of Epoxy Repair projects and Client Nanes

3. Adhesive Ingineering Publication "Construction"

Article on Largest Epoxy Irijection Repair Ever Campleted - Construction . Adhesive Bonding was Contrector

4. Guideline - Structural Concrete Eonding Process

5. Product Selection Chart

Structural Concroto Booding $\$$

Eaklanty

Coneresiven 6

Potymer Coscento

Contings 
WHC-SD-WM-ER-568 Rev. O

This page intentionally left blank. 


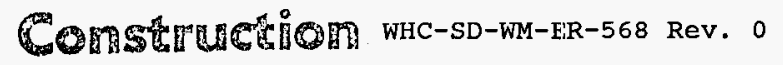

Alhesives

Bondires

I:xe.

1733 thes 7 h stost

Cherloria, Norti Carollos 20200

\section{COMPANY INFORMATION}

CONSTRUCTION ADHESIVES BONDING, INC.

CHARLOTTE, NORTH CAROLIIIA

CHARLESTON, SOUTH CAROLIMA

SEPTEMBER 1982

Structural Coacreto Dondiag(8)

Soslents

Conctevivese

Polymer Comerato

Coatings

Tolephones:

Structural Evaluations

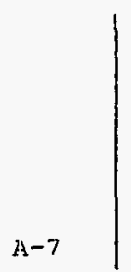

Office-704-375-3427

Nights-704-542-2223 
WHC-SD-WM-ER-568 Rev. 0

This page intentionally left blank.

$A-8$ 


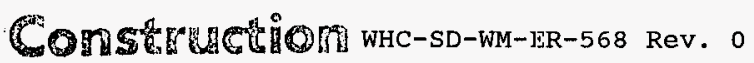 Adhesives Sonding \\ Inc.}

\section{THE COMPANY}

CONSTRUCTION ADHESIVES BCNDTNC, INC., was established to combine professional skills of engineers and advanced techrology of epory injection to the repair of damaged structures using qualified persomel. Our unique service of total concrete rehabilitation has experienced a steady and progressive growth in this segment of: the concrete construction market. Our company has successfully perfonmed a wide variety of repair. procedures for federal and state govemments, uilities and private industrial clients.

Our company's success is primarily attribured to the use of totally qualified staff trained and certified to perform to the highest standards of the engineering and epoxy specifications. Euch professional and techical. staff member has a spectalized bacirground in structural engineering, epoxy injection, concrete purping, overlays, protective coatings and linings,

It is the standard of CONSIRUTION ADHESIVIS BONDING, INC, to provide the highest quality for a total repair system. Our company goals and adninistrative philosophy have been established and implemented to achieve our reputation in this field.

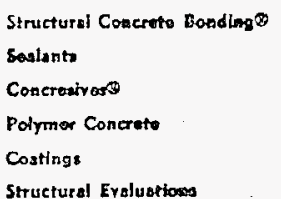

A -9
Tolephor:s:

Offico-704-375-2427

Nighti--704-542-2223 
OMSTH

ATResives

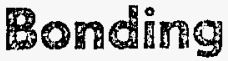

In:

CONSTRUCTION ADHESTVE DONIING, INC., can dhaw on the resources

of the parent corquarly, Arlhesive Engineering Coriony, the sole pioneer

and leading mufactor of epoxies and injection systens for more than

25 years.

Structural Concrote Bondingo

Sealantx

Concreviveres

Polymer Corrcroto

Coxtings

Tedeplones:

Structural Eraluatione

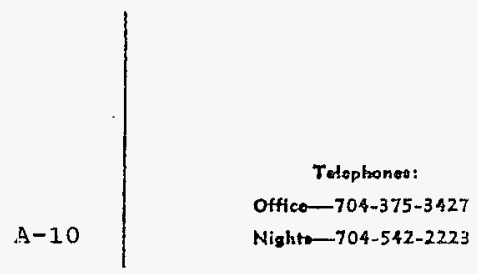


6\%

A dhesivas

Bonding

Ine.

PROJICT

Repair of cracks in turbine pedes'al

at San Juan Generating Station

Epory injection on mortar joints in

bridge abutments built in 1890 .

Repair of cracking in post tensioned

earthquake resistant bridge.

30 Miles of concrete crack repaired

in hyperbolic natural draft coolirig

tower.

Repair of cracked grain elevators.

Repajr of bridge deck cracking.

Repair of cracked bridge members.

Siructural Concreto Bosdingo

Soxalanio

Concrealvose

Polymer Concrats

Costings

STuctural Evalentions

A-11
CIIENT

New Mexico Public Service

Southerm Railway Systen

I). S. Dept. of Interior

Mississippi Power and Light Co.

South Carolina State Port Authority

Seaboard Coastline

Seaboard Coastline and N. C. Ilept. of Tramsportation
Teloptrones:

Offleo-704-375-3127

Nighto-704-512-2223 


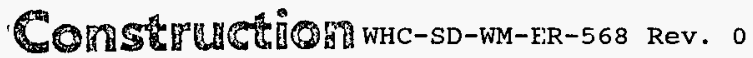 \\ Aotosiver \\ sonding \\ lue.}

PROUECT

Waterproofing of leaking concrete

cracks.

Waterproofing of leaking concrete

cracks.

Deteriorated surface repaired in

aluminum casing plant.

Structural cracking repaired in

colums and beans.

Repair of leaking cracks in reclaim

tumel.

Repair of 28 cement silos cracked

in explosion.

Repair of leaking intake structure.

Repair of 32 cracked precast colurns.

Cracked 500 FP motor foundation

repair.
ClIENT

U. S. Anry - Ft. Bragg

South Carolina Public

Ssrvice Authority

Alumax of South Carolina

Campbel1 Sam Co.

South Carolina Electric

and Gas Co.

Dindes Cement Corp.

Carolina Power and Light Co.

Catawiba College

Colonial Pipeline Co.

Structural Cowereio Bondiags

Sapiente

Concroatro:

Potymer Comerets

Coating:

Tolophonea:

Structural Eraluatkes 


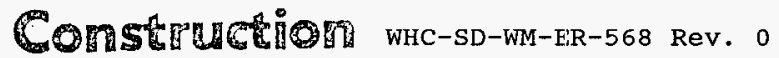 4hasives \\ Pornding

PROJECT

Repair of cracked prestressed double:

tees.

Repair of beans, colums and slabs in

Central Library.

Repair of cracked precast walls.

Repair of cracked concrete piles.

Repair of 230 tan forging press

foundation.

Repair of cracked and voided piles underwater.

Repair of cracked concrete silo

corplex.

Tiles rebonded in chenical reactor.

Cracked floors and tarks repaired.
CI_IENT

U. S. Air Force

University of North Carolina

Schilitz Brewing Co.

North Carolina Dept. of: Thans.

Teledyne AIIVAC

North Carolina DOT

Martin Marietta Chenicals

Georgia Pacific

Al ied Chenical Co.

Structural Coscrote Bandirgo

Sonlente

Contrestroos

Polymer Coscroto

Costing:

Structural Evaluetiosa 
WHC-SD-WM-'ER-568 Rev. 0

This page intentionally left blank. 


\title{
WHC-SD-WM-lER-568 Rev. 0
}

\author{
TABL.E CF CONTENTS \\ TECHNICAL SFECIFICATION RO \\ FOR \\ HANFCRO WORKS \\ HANFORO, WASHINGTON
}

T.O SCOPE

2.0 CODES ANO STANDARDS

3.0 MATERIALS

4.0 QUALITY CONTROL REQUIREMENTS

5.0 EQUIPMENT FOR METERING, MIXING ANO INJECTING

6.0 EXECUTION OF WORK 
WHC-SD-WM-ER-568 Rev. 0

This page intentionally left blank. 
WHC-SD-WM-ER-568 Rev. 0

TECHNICAL SPECIFICATION

FOR

EPOXY INJECTION REPAIR ANO NONOESTRUTTION EVALUNTION OF

MONORAIL SYSTEM BUIL.DING 22.5. B

$1.0 \quad 5 \mathrm{SCOPE}$

1.1 It shall be the intent of this specification to produce a water tight concrete veil through the pressure injection of a thixotropic epoxy adhesive into voids at the horizontal construction joints hereinafter referred to as inter-lift voids. Therefore, this specification defines all the work including materials, equiprent, and execution for the sealing of the inter-lift areas by the pressure injection of a thixotropic epoxy adhesive at the locations shown on the drawings (listed in Exhibit $E$ ) and all others that leak.

\subsection{CODES AND STANDARUS}

2.1 Any material or operation specified by reference to the pubilished specifications of a manufacturer, the American Society for Testing and Haterials (ASTM), Americar Concrete Institute (ACI), American Helding Society (AWS), the Concrete Reinforcing Steel Institute (CRSI) and the American Institute of Steel Construction (AISC), Prestressed Concrete Institute (PCI), or other published standards shall comply with the requirements of the current specifications or standards iisted. In case of conflicts between the referenced specifications or standards, the one having the more stringent requirements shall goverm. All ASTM referrals shall be the latest ssue including tentative issues, unless otherwise indicated.

2.2. Materials to be in accordance with:

ACI 503 Use of Epoxy compound with concrete.

Manufacturer's instructions for use of Epoxy adhesives.

ASTM D 695 Compressive Properties of Rigid Plastics.

ASTH C 42 Standard Method of obtaining and testing drilled cores and sawed beans of concrete. 
3.0 1077-7 is a radiation resistant 2 component epoxy designed for crack injection and use with the Strustural Concrete Bonding injection pump. It is a thin epoxy material and has been used extensively in the repair of concrete in nuclear power plants.

The material has been used in such project as Turkey Point, Brown's Ferry muclear Power Plant, Pi igrin Point Nuclear Power. Plant, Vellecitos Padio Isotopes Plan:, Diablo Canyon Power Plant, Rjchland Power Plant and severil other Nuclear Power facilities.

\section{CONCRESIVE $1077-1$}

3.1 Concresive 1077-1 is a low viscosity, two component epoxy designed for crack injection. It is resistant to radiation and bonds to damp concrete.

\section{DESCRIPTION}

Color Part A: white liquid; Part B; brown liquid;

\begin{tabular}{ll} 
Viscosity at $77^{\circ} \mathrm{F}$ Part $\mathrm{A}$ : 890 cps; Part B: 520 cps: \\
\hline
\end{tabular}

Mixed: $640 \mathrm{cps}$

Pounds per Galion: Part A: 9.6; Part B: 8.7; Mixed 9.3

Mix Ratio: By weight : 5 par:s "A" to 3 parts " $B$ "

By volume : 3 par"s "A" to 2 parts "B"

Pot life: One pound mass $07^{\circ} \mathrm{F}-27$ minutes

Cure time: $\quad 7$ days $\quad 77^{\circ} \mathrm{F}$. Sufficient strength for normal handling is usuall? achieved in 24 hours.

\section{PROPERTIES OF. CURED ADHESIVE} (Cure 7 days $\left(77^{\circ} \mathrm{F}\right.$ )

Thin film set time $077^{\circ} \mathrm{F}: \quad 4$ hisurs

Tensile strength $77^{\circ} \mathrm{F}: \quad 3600$ PSI

Tensile elongation $077^{\circ} \mathrm{F}: \quad 27 \%$

SURFACE PREPARATION:

See Technical Buljetin AE - 100, titied "Surface Pretreatment for Adhesive Engineering Epoxy Resin Based Adhesives."

\section{CLEAN-IJP}

Equipment should be cleaned with toluane before hardening of resin. If hardening has inadvertently taken place, soaking in methylene dicloride is the only practical method of cleaning. 


\subsection{Surface Seal Ad!esive}

The surface seal material shall consist of Concresive $142 \%$ for temperatures below $80^{\circ} \mathrm{F}$ and Concresive 1438 for temperatures above $80^{\circ} \mathrm{F}$. Fine aggregate may be added to the surface seal material when thickness in excess of $1 / 4^{\prime \prime}$ is required. The arwunt of aggregate to epoxy loading shall be $7: 1$ by volume. Consult the epoxy formulator for recomiendations on optimum aggregate gradation.

These materials shail be certffied by the manufacturer to have the following properties:

\section{2 .1} CONCRESIVE $14 \% 2$

Form: Two-component, thixotropic paste.

Color: Part A -. vhite; Part B - black; Mixed - light concrete grey.

Mix Ratio: I part: "A" to I part. "B" by volume.

Pot life in a one callon mass: 40 minutes a $70^{\circ} \mathrm{F}\left(21.1^{\circ} \mathrm{C}\right)$

Slant Shear Strength at $26^{\circ} \mathrm{F}\left(-3.3^{\circ} \mathrm{C}\right)$ after 20 hour cure per AASHTO T-237. Bondi ine thickness is $1 / 16^{n}$ to $1 / 8^{\prime \prime}$. 90 mirutes 5000 psi (no failure)

Compressive Strength after 20 hour cure at $26^{\circ} \mathrm{F}\left(-3.3^{\circ} \mathrm{C}\right)$ ASTM C-116-68 6500 psi

Tensile Strength: 3500 psi -

Form: Two-component thixotropic paste.

Mix Ratio: $A: B$ 2:1 by volume

Pot life, 200 gram mass $077^{\circ} \mathrm{F}: 32$ minutes

Slant Shear Strength, psi* AA:iHTO T-237 5000 (Dry concrete)

*Cure Schedule: 24. hours $77^{\circ} \mathrm{F}$ - Test Temperature: $77^{\circ} \mathrm{F}$

- Compressive Yield Strength, psi ASTM D-695 8000 Tensile Strength. fsi ASTH D-638 3000 
4.1 The quality control tests and methods described for each material in Section 3.0 are required for every lot of adhesive supplied under this specification.

4.2 Certification and Test Report - Manufacturer shall certify that every batch of material supplied to this specification meets all of the requirenentis of this specification. The certification shail include results from all of the tests listed.

4.3 All materials shall be mixed and used in strict accordance with the manufacturers' published spacifications and directions with special attention given to use within specified time limits.

\subsection{Materials Comoliance Prior to Shipping}

\subsubsection{Materials Properties Tests:}

Prior to shipment to the field the injection materials shall be tested for comiliance with product materials specifications listed in Section 3.0. Materials failing to meet specifications shall not be shipped to the field. Materials passing shall be certified as having passed and shall be shipped.

4.4.2 At the time of materials testing, control samples shall be made and subjected to Shore hardness D tests. These test results shall be provided with the certification as provided for in these specifications.

\subsection{Materials Compliance at Point of Placement}

4.5.1 During ratio testing in the field, samples shall be taken at intervals prescribed in Section 5.0 and subjected to a Shore hardnrss $D$ test. A companion sample of epoxy shall also be taken with each shore hardness D sample using a standard $1 / 2$ inch by 4 inch test tube. Field samples shall be logged on the forms provided for in Section 6.0 .

\subsection{Labeling, Packaging, \& Storaqe}

4.6.1 Label Information - The label shall include, in a clear and distinct manner, the following information:

a. Product name and lot number.

b. ANSI Hazard Classification (fomerly SPI Classification) and appropriate recomended ANSI precautions for bandling. 
WHC-SD-WM-ER-568 Rev. 0

c. Hix ratio by volume.

d. Packaging . The achesive material shall be packaged in new, sealed containars. Each container will be clearly labeled.

e. Storage . The containers of the adhesive shall be stored at ambient temperatures below $120^{\circ} \%$ and above $32^{\circ} \mathrm{F}$. if stored at temperatures cutside these inits, the adhesive materia shall be tested at the contractor's expense prior to use to deternine if the adhe-sive material meets the requirements of this specification.

\subsection{Special Precautions}

Epoxy materials are toxic before cure, therefore, avoid inhalation of vapor and contact; with skin and eyes. Always wear goggles and gloves when working with the components.

Do not use in enclosed spaces unless adequate yentilation is supplied.

\subsection{EQUIPMENT FOR METERING, MIXING \& IMUECTING}

\subsection{Type}

The equipment shall be capable of simultaneously metering, mixing and dispensing the mixed material at pressures in excess of 200 psi. The mixed material shall hove no streaks or lumps which would indicate improper mixing. The equipment shall consist of the following comporents:

a. Two Pressure feed drive fumps; one for each component, air operated.

b. One propartioning rodule.

c. One dynamic mix head, air operated.

\subsection{Discharge Pressure}

The injection equipment shall have the capability of discharging the mixed adhesive at pressures $\mathrm{ep}$ to $200 \mathrm{psi}$ and maintaining that pressure.

\subsubsection{Test for Pressure Check}

\section{a. Hethod}

The mixing head of the injection equipment shall be disconnected and the two adhesive component delivery lines shall be attacted to the pressure check device. The pressure check device shall consist of two independent valved nozzles capable of controliting flow rate anc pressure by opening or closing the valve. 
There shall be a pressure gauge capable of sensing the pressure buill-up behind each valve. The valve: on the pressure clieck device shall be closed and the equipment operateil until the gauge pressure on each line reads 160 psi. The pumps shall be stopped and the gauge pressure shall not drop below 150 psi within 3 minutes.

b. Erequency of pressure Check Test

The pressure checl test shal] be run for each injection unit at the leginning and mid-point of every day that unit is ised in the work of crack repair.

\subsection{Proportioning the Adhesive Conponents}

\subsubsection{Ratio Tolerance}

The equipment shall have the capability of maintaining the mix ratio for the injection adhesive prescribed by the manuracturef of the adhesive (paragraph 2.1) within a tolerance of $? 5 \%$ by volume at any discharge pressure up to ico psi.

\subsubsection{Method}

a. The mixing head of the injection equipnent shall be disconnected and tive two adhesive components shal] be purned simultaneously through the ratio check device. The ratio check device shall consist of two independent valved nozzles capable of controllin! flow rate and back pressure by opening or closing the valve to restrict material flow. There shall be a pressure gauge capable of sensing the back pressurs behind each valve. The discharge pressure shall be adjusted to $160 \mathrm{ps}$ i for both adfesive components. Both adhesive components shall be simultaneously discharged into separate calibrated containers. The amounts discharged into the calibrated containers simultaneously during the same time period shall be compared to determ ne the mix ratio.

After the test has been completed at a 160 psi discharge pressure the: procedure shall, be repeated for o psi discharge pressure.

\section{b. Frequency of Test for Prover Ratio}

The ratio test shall be run for each injection unit at the beginning ard at mid-point of every day that unit is used in the work of crack repair. 
5.3.3 Proof of Ratio and Pressure Check

At all times during the course of the work the sub-contractor must keep complete and accurate records available to the oviner or his agent of the ratio check tests described in paragraph 5.3.2 and the pressure check tests described in paragraph 5.2.1.

In addition, the owner at any time without prior notification may request the sub-contractor to conduct the. tasts described in paragraph 5.3 .2 in the presence of the owner or his agent.

\subsection{EXECUTION OF WORK}

6.7 Extent of Work

Inject all voids as identified by the drawings $R C-1$ or as directe by the Engineer.

Hote: The drawings do not necessarily indicate all the voids tha leak and therefore have to be injected.

\subsection{Procedure}

\subsubsection{Crack Preparation}

Before repair work begins all cracks must be free from loose matter such as dirt or laitance and free from oil, grease, salt or any otrer contaminants. If upon inspection of the crack surface any of these contaminants are found, a procedure in compliance with this section of the specifications shall be submitted to the Engineer for Approval prior to inspection of the void.

\subsubsection{Crack Sealing}

Prior to injection of the crack a surface seal material shall be applied to the face of the crack (refer to Section 3.0).

\subsubsection{Preparation for Injection}

a. Drill holes into the defective area and blow out dust with compressed air.

b. Bond injection ports into drill hole with surface seal material. Either pipe nipples or plastic tube may be utilized.

c. Space ports no less than the thickness of the concrete but no more than 1.5 times the thickness of the concrete. 
d. Seal the defective area with surface seai material.

6.2 .4 Injection.

Attach the injection nozzle lo injection port and pump material until refusil, appearance on the outsice surface or appearance at an adjacent injection port. At. this point, discontinue injection at this port chi move to the adjacent port. Continue this procedure unti? the void is rijled.

\subsubsection{Monitoring Floy Gauges}

a. Form

A fon. shaly be teveloped and maintained by the subcontractor (approvad by the Engineer) to assure prope perfomance of the equipment between periods of test. ing. These fams shall contain as a minimum the foljowing information:

(1) Material identification and sample number

(2) Location of work perfomed

(3) Flow gauge reidings

(4) Heather condivions

(5) Operators

(6) Calibration and checkout information

(7) Any abromalities of equipment or process

b. Freguency of Monituring

Flow meters shall he read every half hour while pumps are in operation and reading recorded on forms described above.

\section{c. Acceptance}

If the ratio is of: more than $5 \%$ pumping shall be discortinued until the problem is corrected and flow gauges indicate normal acceptable flow ratios.

\subsubsection{Finishing}

After the injection adhesive has cured, the surface seal shall be removed. The face of the crack shall be finishe flush with the adjacent concrete. There shall be no indentaticns or protrusions caused by placemerit. of entry ports. 
WHC-SD-WM-1SR-568 Rev。0

\subsection{EPOXY INJECTION EVALUATICI}

a. Pulse echo techniques shall be employed to evaluate the penetration ard bond characteristics of the epoxy injection.

b. Attached specification shäl be used. 
WHC-SD-WM-EF-568 Rev. 0

This page intentionally left blank. 


\author{
WHC-SD-WN-ER-568 ReV. 0 \\ THuencter and ofdsociaten, $O_{\text {AsC. }}$. \\ MATERIALS ANO NONOSSTFUCTIVE TE. IJING \\ 3:140 HUNTCUFF UR \\ CHARLOTIE. NORTH GARQIINA $28: 11$ \\ (704) 3:7 4041 - $(704) 542: 2223$ \\ TEST PROCEDURE. FOR \\ MICROSEISMIC EVALUATION OF CONCRETE \\ (PuTse Echo Method)
}

1.0 TEST DESCRIPTION ANO OBJECTIVES

This procedure establishes a systematic method for perfomaning nondestructive volumetric examination of in-place con. crete using the microseismic test method. This test method is based on the laws of wave propagation through an elastic mediun and is perfomed usins electronic equipinent utilizing the theory of randarn signal analysis. The location and extent of internal discontinuities in existing concrete. can be determined by interpreting microseismic test results.

2.0 THEORY AND TEST PARAMETERS

Data from the microseismic tests is interpreted utilizing the aws of wave reflection. The attached cketches designated $A$ and $B$ illustrate oscilluscope signals obtained from two specimens of concrete. In sketches $A$ and $B$, the signal feature noted as (1) is an indication of the wave generated at the surface on which the receiver (transducer) and impactor (mechanical wave producer) are piaced. The signal feature noted as (2) is an indication of the wave reflection from the rear surface.

Sketch A represents a signal from a concrete specimen with no internal discontinuities. Sketch 8 represents a signal from a concrete specimen with an internal discontinuity at approxinateiy one-half the distance between the front and back surfaces. The signal feature noted as a reflector is an indication of the wave refiection from the discontinuity.

3.0 EQUIPMENT

Equipment consists of:

(a) Cathode Ray Tube (CRT) for visual display of signal.

(b) Time base generator for microsecond measurements.

(c) Amplifier and processor circuitry for signal voltage measurements.

(d) Electro-mechanical transducer (receiver) with piezoeiectric and accelerator elements. 
(e) Impactor (mechanical wave cenerator) used to produce wide band frequency stress wave.

(f) Couplant for contact of transducer (receiver) to the test specimen if required by surface condition. Liquid soap may be used for surfaces with irregularities of $1 / 8$ " or less, grease for sur. faces with irregularities of $1 / 8$ " or iore.

(s) Camera for recording CRT signal.

4.0 CALIBPATION AND PERFORMANCE OF EQUIPMENT

4. T The microseismic test apparatus consists of a Cathode Ray Tube, timing device, amplitude device and transducer. The tine base generator circuit is calibrated to a standard traceable to the Mational Bureau of Standards by an authorized service agency. Calibration frequency is 12 months.

4.2 The impactor (mechanical wave producer) is a rebound hammer conforming to ASTH Standard Test Method for Rebound Number of Hardened Concrete, ASTM bisignation: C805. The rebound hammer has a specific rebound characteristic from a known mass.

4.3 Microprocessor anplification circuitry and transducer perfornance are verified by testing for a full scale deflection of the CRT signal. This is accomplished by performing a microseismic test on a slected concrete specimen after setting the oscilloscope amplitude device to approximately 1 volt/cm for every foot of specimen thickness. The test specimen will be selected by the microseismic test equipment operator. This microprocessor and transducer perfomance-test will be performed on the same selected specimen prior to and after completion of the day's testing. The test shall be performed by the microseismic test equipment operator and witnessed by appropriate parties.

\subsection{PERSONNEL}

Personnel perfoming testing in accordance with this procedure shall be experienced ard qualified. Criteria for qualification shall include:

(a) Prior experience with microseismic test equipment. 
WHC-SD-WM-ER-568 ReV, 0

(b) Experience in interpreting microseisnic data.

(c) Certification in accordance vith ASME, Section III, Uivision 2 and ANSI N45.2.6 (if required).

\subsection{ENVIOROHMENTAL CONDITIONS}

Testing may be conducted under wide range of ambient ten-perature conditions and with est surface either wet or dry.

\subsection{DAILY TESTIRG SEQUENCE}

(a) Perform microprocessor and transducer performance - test (see Section 4.3) prior to start of day's testing. Record on the Transducer Perfornance Test Record (Attachment 1) date of tcst, test specimen thickness, equipment and hanner identification number, time of test, signature of the microseismic test operalor and signature of the test witness.

(b) Inspect the test area for roughness of concrete surface and determine couplant requirements, if any.

(c) Record test area identification, date of testing, test area description, equipment ideritification number, hanmer identification number and signatures of the microseismic tes: operator and test witness on the Microseismic Test Record (attachrent 2).

(d) Connect all wires to interface DRT with microseismic processor. Energize system with 110-120 yolt $60 \mathrm{~Hz}$ electrical power.

(e) Set controls for predetemined depth inspection.

(f) At each test location apply couplant, if required, to the concrete surface or rubber face of transducer and place transducer firmly against test surface.

(g). Place impactor (mechanical wave producer) against test surface approximately 1 " away from transducer. Trigger impactor.

(h) View the CRT signal.

(i) Identify signal features in tems of internal discontinuities causing reflectors.

(j) Record wave travel time for computation of pulse velocity if required by test specifications.

(k) Photograph the CRT signal. Photographs will be taken at test locations exhibiting reflectors as 
directed by the field erigineer. The back of all photographs will be labeled with test date, a sequencial photograph identification number, test area number, and test grid lacation. Video tape recording is also available for test data records when required.

(1) Pecord test grid location, specimen thickness, presence of reflectors, photo number with applicable remarks on Microseismic Test Record form. (Attachment 2).

(m) Proceed to next grid location to be tested.

(n) At cornpletion of area testing prepare field sketch of test area. (Optional)

(o) Upon completion of the day's testing, perform transducer and microprocessor performance tests (see Section 4.3) and record appropriate information on the day's Transducer Performance Test Record, (Attachment 1).

\subsection{RECORDS}

A1) personnel qualification certifications, equipment performance, field sketches and microseismic tests results will be documented. The records shall be complete and signatures provided where indicated. Photographic records of all tests shall be traceable to the applicable test. Copies of all records shall be maintained by Muenow and Associates, Inc. or as directed. Video tape recording of a)1 test data is available when required. 


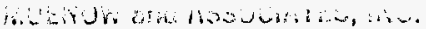

Nhaterisls and liondestruct WHC-SD-WM-ER-568 Rev * 0
3940 Huntchif Dri

CHARLOTTE, NOFTH CAROLINA 23211

(704) $377.4041 \quad 542 \cdot 2223$

CHECKOBY

DCALE.

TTPACHMENS 2

MICROSEISMIC TEST RECOND

Pg. of

MLST AREA

DATE

F.REA DESCIIPTION

EQUIPLENT ID. NO.

HAMHER ID. 10.

PERFORMEI BY

WI TruESSED BY

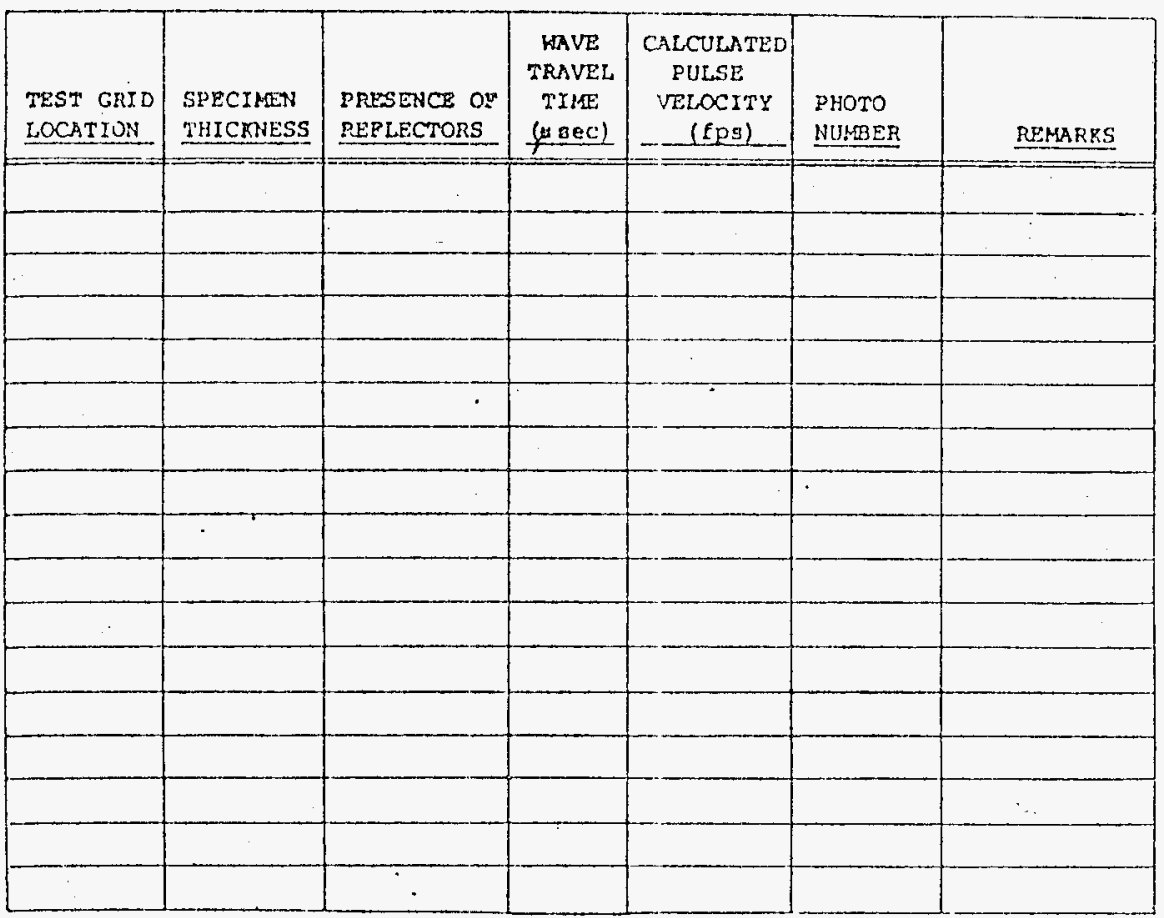

$A-31$ 
CHARLOTTE NORTH CARC WHC-SD-WM-ER-568 REV - 0

$(704) 377-6,041$. $542-4.4 .4 .5$

checken ir

OATE.

ocale

ATTACHMEN' $]$

TRANSDUCER PERFORMANCI IEST RECORD

P. OE

DATE

SPECIMEN THLCRNESS

EQUTPHENT ID. NO.

HAMNER ID. NO.

PERFORMANCE TEST PRIOR TO TESTING

- $\quad$ TIME

PERFORMED BY

WITNFSSED BY

PERFORMANCE TEST AFTER COMPLETION OF TESTING

TIME

PERFORMED BY

WITNESSED BY

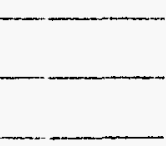




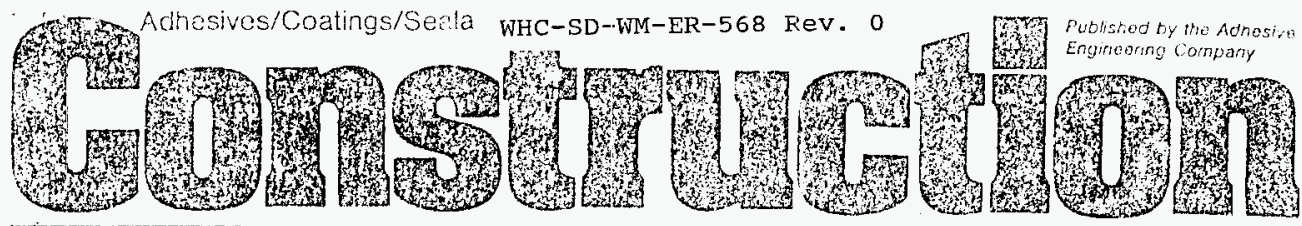

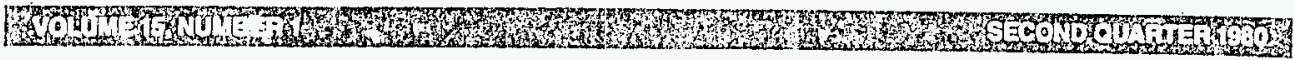

Aobesine ing

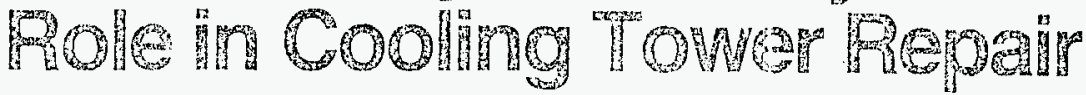

7 wo years aber a eoming cower

Ei sippi nuclese powtr plint wes

1 xtensively llamated durink a tornado

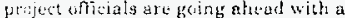
ihrta-fold repair method which will per andunty resore the suructure to its de signed witerrity. The repair scheme, which cunsisty of replucing the concrete in large leter in the tower's rim, rebonding ubriruximately two moles of rninute cracks b) epoxy arditesive ins action, and fitting

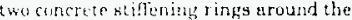
wrer is ryproded to be complete before the plane poes on line in late 1983

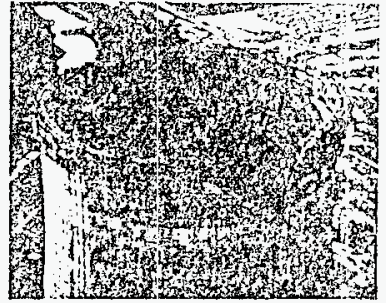

The emedial wort was made necessury when, in April 1978, e small tornado ripped through the jobsile where Bechtel Fower Corporation is constructing the Grand Guif Nucloar Suation fur iss owner. Middle South Energy, Inc. MSE: The bigh wind were acrong enowh to topple a 500-foct tall tower crane, bending the bong crething through the rim of the cooling tower and creating a 150 fort wide by 75 -foot decp tear in the concrete. Addi. tionaliy, the combined forces from the tigh winds and crane impact produced a small localized inward butkle and many ritinute cracks in the reinforced shell.

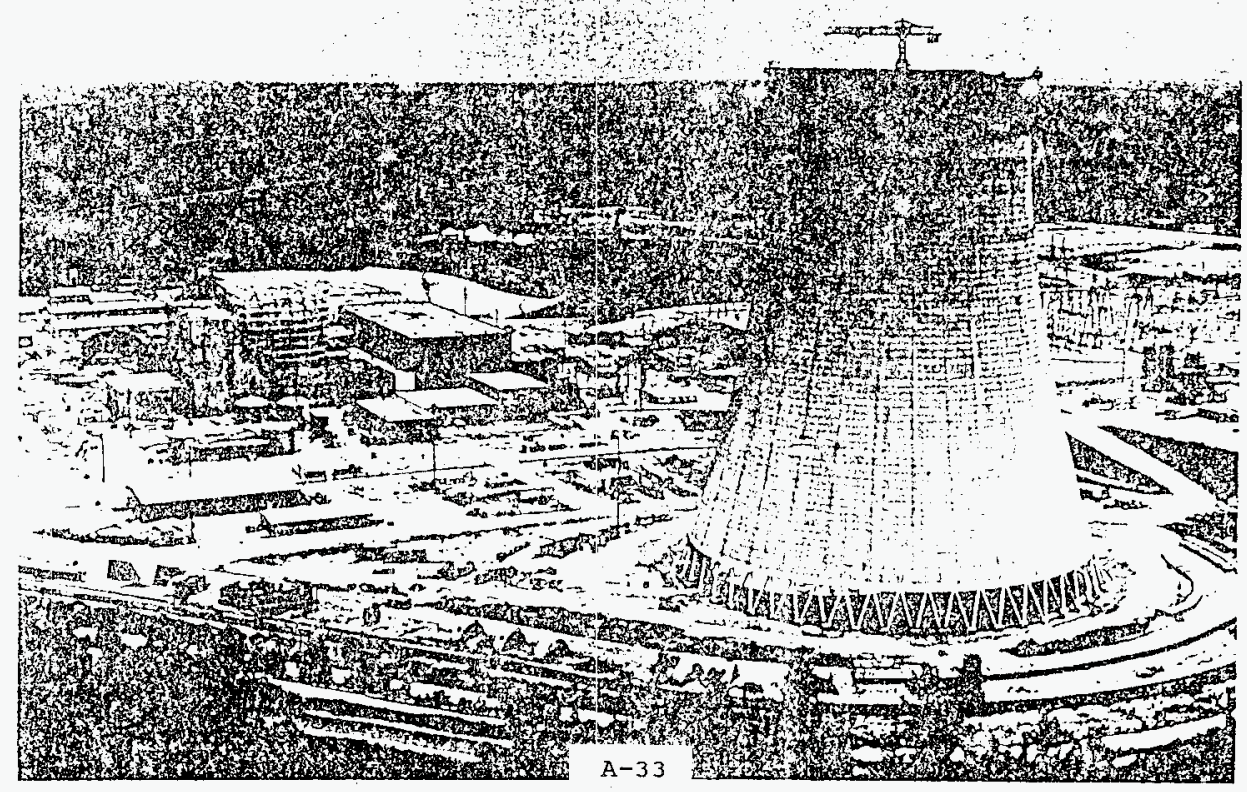


licgutir or babula

Fisluation ly several fitmo began

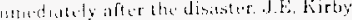

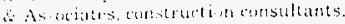

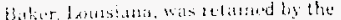

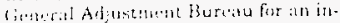

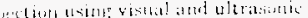

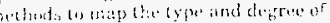

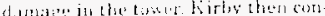

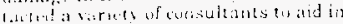

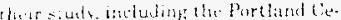

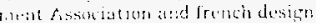

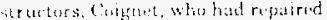

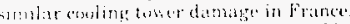

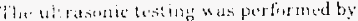

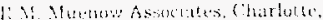

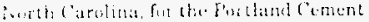

\section{wiation.}

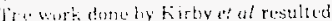

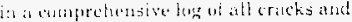

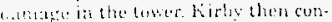

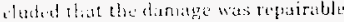

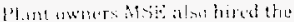

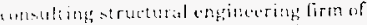

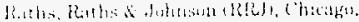

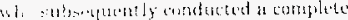

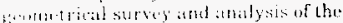

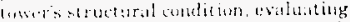

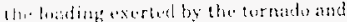

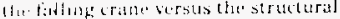

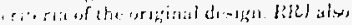

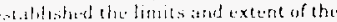

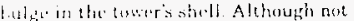

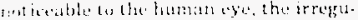

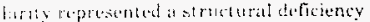

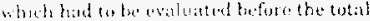

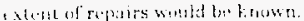

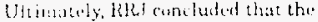
$\therefore$ ruldure cauld be afferevely restorad and

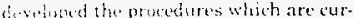

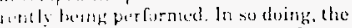

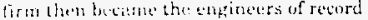
lite the repute ot the lower

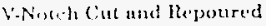

lo April lo80 tower constructurs

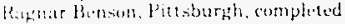

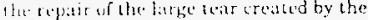

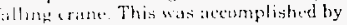

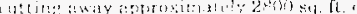

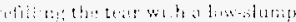

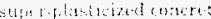

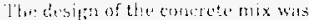

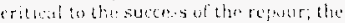

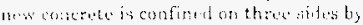

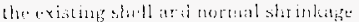

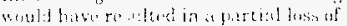

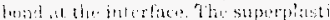

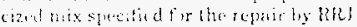

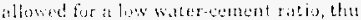

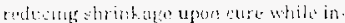

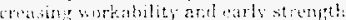

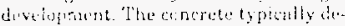

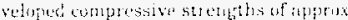

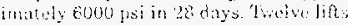

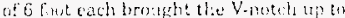
the lesel of the cxistume ritis and corrcludel that phase ot tiac repatr.

SC) 3. Injection

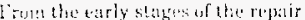
cunceptatization. A.dhe dive lisp.:

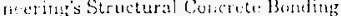

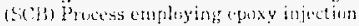
sis andsiderud as the methigh by which all cratks 5 mila or wider in the tower watd be recomelidised. The funetion of

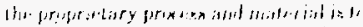

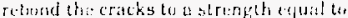
that of the concrote and to resture the

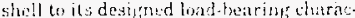
Leristics. The irjection process alsos serve to protect the reintorcing ster! from wated entry and sulisequenc comosiuth.

hes subcontract fot al! epoxy. irjeccion work was given to Comentriction! (Adhesive Bonding 7 5 (CA B), Charlote,

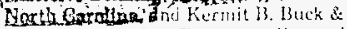
Gun, Inte., Menuphis, Tennussca, licensed applicutors for Adhusive Fingineerings injectons system. A part trom CAB's capabilities in concrete bouding, Richard Munow the Frasidint of C:AB had perfurmod the intiol ultra sonic testingt un the linwer and was very famitiar wis the scope of the remedial procedures.

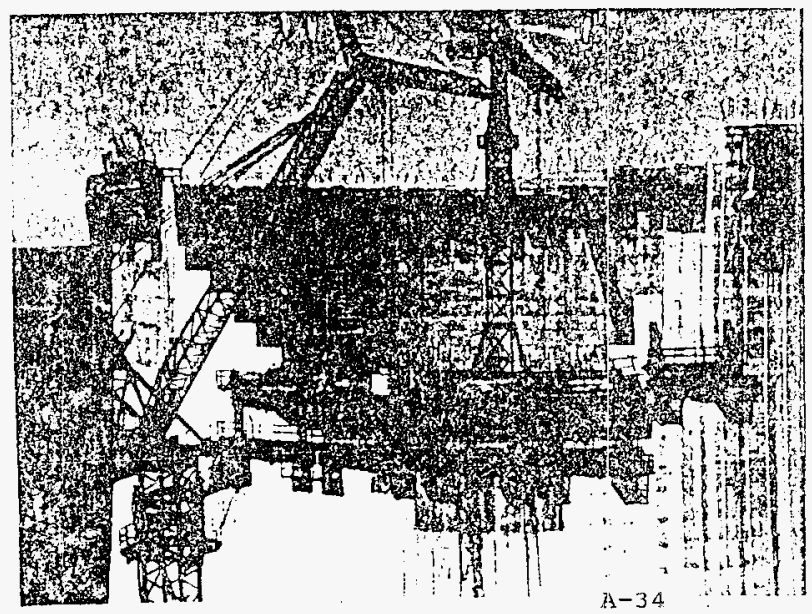

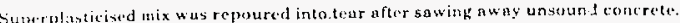

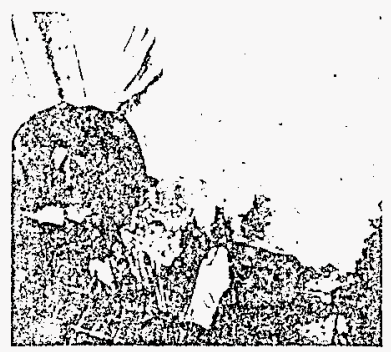

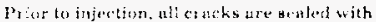

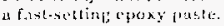

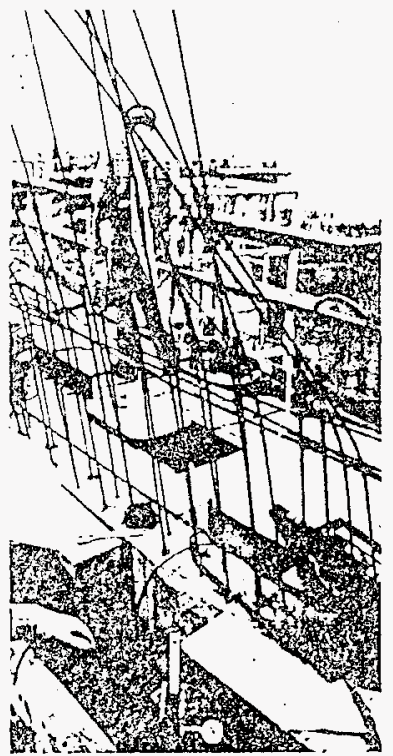

brossura injection by the SCIB Frocests reatores struitural integrity tu cratked areas.

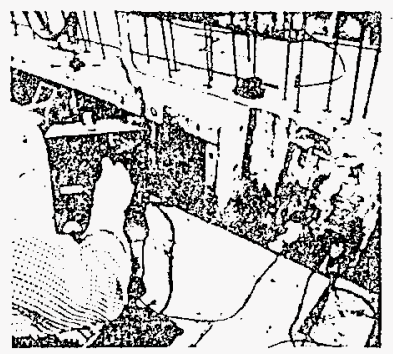

Nun-destructive ulerasonic esting confirms culledepth penetratisa of the adhesive. 


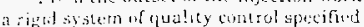

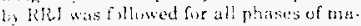

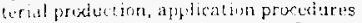

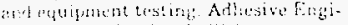

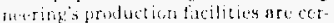

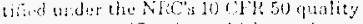

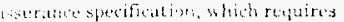

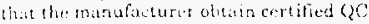
Lavit reports frum exilt ruw material

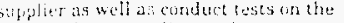
fi:al pos duce according to the Encifications for the job Corenesives

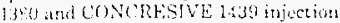
ainowists are the products specified ot

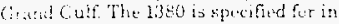
jetrin at temperatures bet ween 40 end

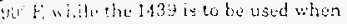
the tenpracure is above 90 l? Each shimments to be acompanied by a cer-

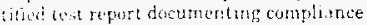
wht the dibsive's specified propertice

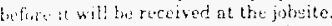

The citulity assirance procdures

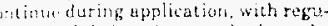

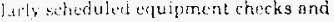

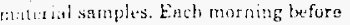
tuftrming injectim, CAB technicians test

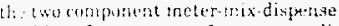
athing for accuracy of pressure, culi.

lor.tim whd ratio. The equement will be s $x$ onl; it it passer a the ic Lesity Addinis!ly. a sample of the ardhesive is col1, drom each pump eight times a day atested wor Shore D) hardue-ss. Each ingyle is labeled with che wenther condi(i) fhis surface tem:perature, location fiphed and the results of the Shure $D$

All sitriples to date have tested basufuckory.

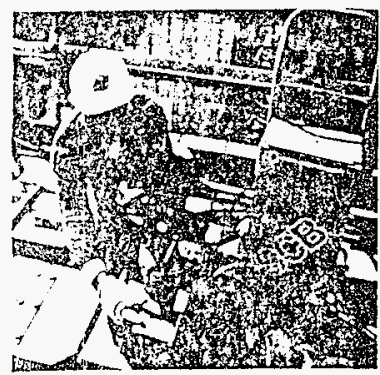

Accursty of injection cquipnent ls checked curh tuotaing be fore work begins.

Bunding Procedures

With miner medificaliums, the injec-

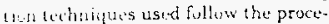
dures deveitupd by Adhesive bingineering wur 20 years ago, burking from eranefidialu? plattorms, wehnicians first trowel a liats - scring epoxy seal over the crack 3 wo strve ts a dura for the injected adhesive iflie creck cetends complet cly thruunh the concrete, both sides are stetted to alluw proper pressure behind the apoxy to furce it completely through the crats white proventing rurouk. When thr. seal hardens. the crack is then Mushed woth hoh-y-essure watur to remove any internal cumtuminatim wich may inlitsit the bond

iniertion begins a! the iowermost purt an vidital cracks, and at one end for

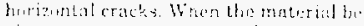

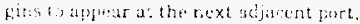

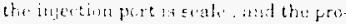

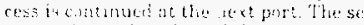

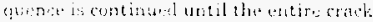
is folled with the adt: sive. Typhesly, the

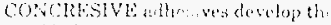
specilet structual gropertics within three doys after injectom

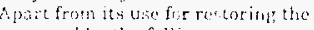
cricts cilused ty the fallims tower ciant

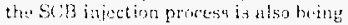

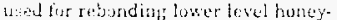
conbing and all eracsing in the vicinity of the fuchorage insters for the slipgernes The method, maturial, and $Q \mathcal{C}$ contruts for the soproblems are identical to thwise fiven above, and have been field tested to

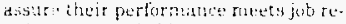
quirementa tand objectives.

\section{Ultrascalc Jeetive}

'The adequacy of adhegive penetration into every crack is co vifred ty nut?ctestructive ultrasoni; testing. The nethexidevelopes was proven for accuracy and relinbility enrly in the repair whase by RRI, who ec mplured the wit:asonic test results with core samples tuken from the same ares.

Basica!ly, the ult resonic methat consigts of transmitting a low fregtemcy sound wave through the concrete ts de. temine its soundnest. Using two transducers (traismitter and receiver) and a soriscope, the pulan velocity value for eound uncracked concrete is first estab. lished as a control. Then the unnsducers are placed on either side of the crack, at a constant distance apart. When the pulse travels through an open crack, the time of travel is siguificantly longer because it has to travel to the root of the crack be fore reachint the recencer and comider.

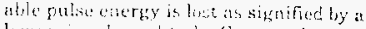

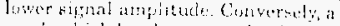
crack which has beter wompletely filled ulth the epoxy adlessive will match the velecty and amplitude values, for that of

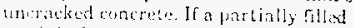
crack is dectected, the wath is imrsediately injected until the leating indicatcy corralde adhesive penetration:

\section{Stiffening IRings}

The Tinal phase of the repair concept incluiles the at cachmest of two external

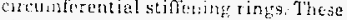
ringu, a combination of bot h a precast form segrient ind work plitternes and cart-in plece concrete vere proprised by ill. to the constructors RBL. The rings are placed around the cower to compens. sate for a srall amant of buckling carac i:y which mey otherwise have leten lost. and to provide additional reinforcemest to control the potential development of new vertical cracking commonly olinerved in older operational towers.

CONCRESIVE 1440 phite adhesive has boen selected for grouting the reinforcement which will be doweled into the shell at each ring location.

\section{Combined Performence}

Although each element of the tower repair solves a particular deficiency, it is only their combined effectiveness that lrings ubout a complet. and relinble solu. tion. 'The yuality control sateguards, con. servative structural appruach, and constant monitoring of all phasess of repair at Grand Gulf pruvide the assurance thre, upun completion, the tower will behave as originally designed. Ts

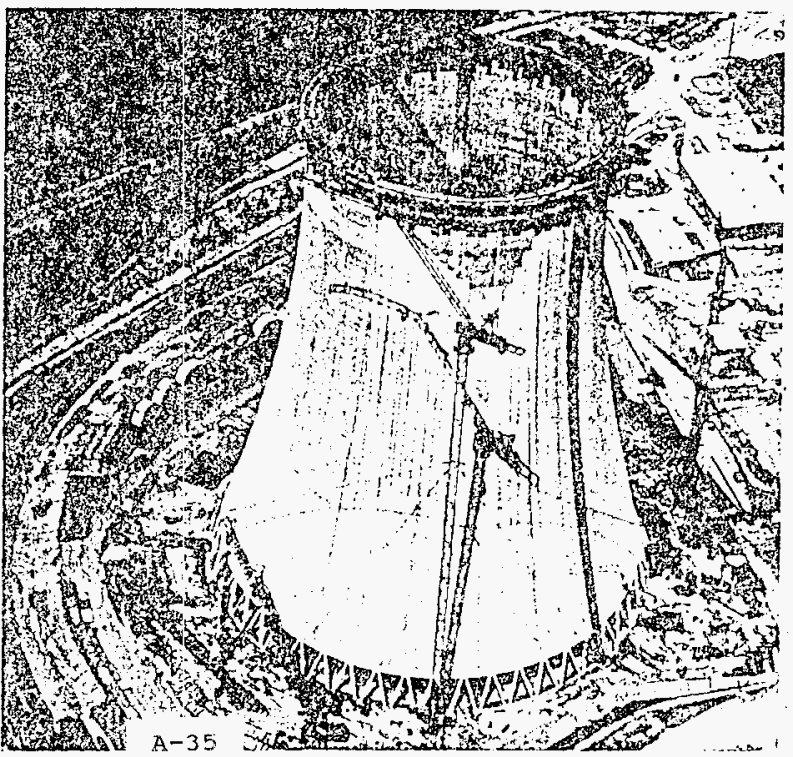

Ali repaics cocooling tower are scheduled fo: completion before plant goes on line in 1981. 
MUENOW and ASSOC WHC-SD-WM-ER-568 ReV. J

Materiais and Nondastrul............. 3940 Huntchllf Drive

CHARLOTTE, MORTH CAROLINA 282!!

(704) $377.4041 \quad 542.2223$

areei rus.

CALCULAT:OOY

CMECKEO UY

DA IE

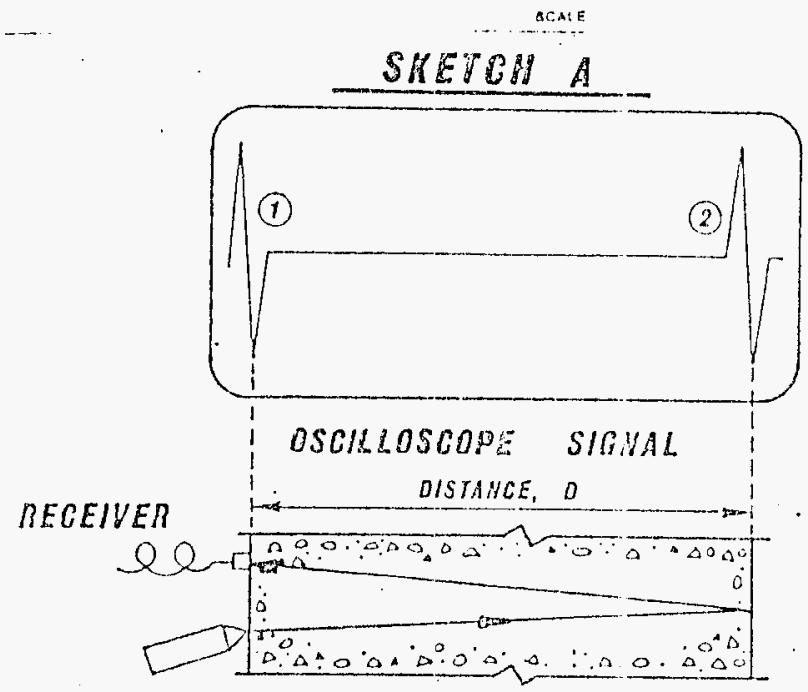

IMPRATOR

CONCRETE SPECIRIEN 1

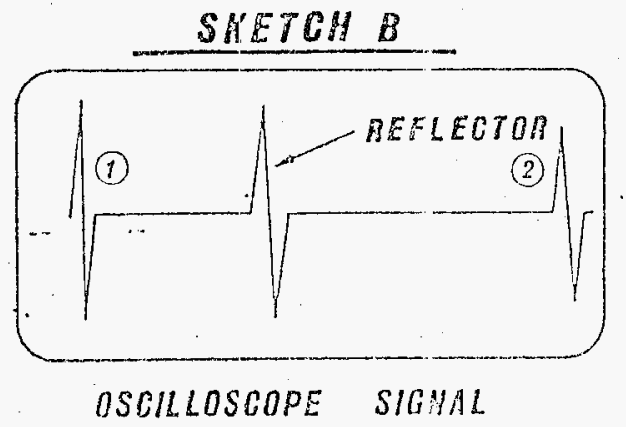

AELEIVER

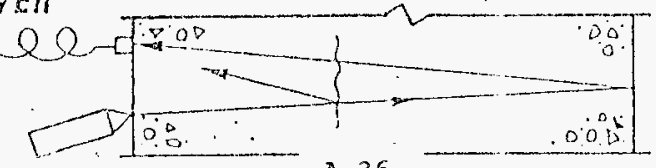

IMPACTOR

CONCAETE SPECIIAEN 2 